\title{
BİLSEM Türkçe Öğretmenlerinin Oyun Temelli Öğretim Yöntemine Yönelik Görüşleri ${ }^{1}$
}

\author{
Gülşah METE \\ Dr. Öğr. Üyesi, Karamanoğlu Mehmetbey Üniversitesi, \\ Eğitim Fakültesi, Türkçe ve Sosyal Bilimler Eğitimi Bölümü, \\ Türkçe Eğitimi Ana Bilim Dalı \\ gulsahmete@kmu.edu.tr \\ Orcid ID: https://orcid.org/ 0000-0003-0979-1630
}

\begin{abstract}
Öz
Bilim ve Sanat Merkezleri (BİLSEM) Türkçe öğretmenlerinin oyun temelli öğretim yöntemi üzerine görüşlerinin değerlendirildiği bu araştırma nitel desende tasarlanmıştır. Görüşme tekniğinin kullanıldığı araştırmanın amacı, BİLSEM'lerde çalışan Türkçe öğretmenlerinin eğitsel oyunlara yönelik görüşlerini belirlemek ve bu görüşlerden hareketle Türkçe derslerinde eğitsel oyunun yeri ve derse katkısı ile ilgili değerlendirme yapmaktır. Araştırmanın verileri Türkiye'nin farklı illerinde görev yapan dört kadın, dört erkek Türkçe ögretmeninden toplanmıştır. Toplanan veriler içerik analizi ile yorumlanarak sonuçlara ulaşılmıştır. Türkçe öğretmenleri, öğrencilerin bizzat öğrenme sürecinin içerisinde olduğu, öğrencilerin yaparak ve yaşayarak öğrenmelerine olanak sağlayan oyun temelli eğitim yönteminin Türkçe dersleri için en etkili yöntem olduğunu belirtmişlerdir. Türkçe öğretmenleri eğitsel oyunları, oyunlarla iç içe olan öğrencilerde konuyu pekiştirmek, konuları güncel yaşamla ilişkilendirmek, kalıcı, etkili ve eğlenceli Türkçe öğretimi yapmak için kullandıklarını belirtmişlerdir. Türkçe öğretmenleri kelime oyunlarını, kart ve kutu oyunlarını, sözel zekâ oyunlarını, hikâye kartlarını, atasözü ve deyim kartlarını, hikâye küplerini, tabu oyununu ve pandomim gibi eğitsel oyunları derslerde kullandıklarını ifade etmişlerdir. Eğitsel oyunlar dört temel dil becerisinde de kullanılmakta ve gerekli görülmektedir. Türkçe öğretmenleri hem eğitsel dijital oyunları kullanmada hem de oluşturmada yeterli donanıma sahip olduklarını bunun için eğitim aldıklarını, araştırma yaptıklarını, güncel bilgileri takip ettiklerini, eğitsel oyunlar ile ilgili akademik çalışmalar yaptıklarını, TUBITTAK projeleri hazırladıklarını belirtmişlerdir.
\end{abstract}

${ }^{1}$ Makale Geliş/Kabul Tarihi: 22.02.2021 / 12.03.2021

Künye Bilgisi: Mete, G. (2021). BILLSEM Türkçe öğretmenlerinin oyun temelli öğretim yöntemine yönelik görüşleri. Kahramanmaraş Sütçü Imam Üniversitesi Sosyal Bilimler Dergisi, 18 (1), 106-130. DOI: 10.33437/ksusbd.885068 
Anahtar Kelimeler: Oyun Temelli Öğrenme, Eğitsel Oyun, Türkçe Dersi, BİLSEM Türkçe Öğretmenleri

\title{
Turkish Teachers’ Views On Game-Based Teaching Method in Science and Art Center
}

\begin{abstract}
This research, which evaluates the opinions of the Turkish teachers in Science and Art Centers on the game-based teaching method, was designed in a qualitative design. The aim of the study, in which the interview technique was used, is to determine the views of Turkish teachers working in Science and Art Centers on the educational games and to evaluate the usage of educational games in Turkish lessons and its contribution to the lesson based on their views. The participants included four female and four male teachers working in different provinces of Turkey. The data were analyzed by using content analysis. Turkish teachers stated that the game-based education method, which fosters a studentcentered learning environment, is the most effective method for Turkish lessons. Turkish teachers stated that they use the educational games to reinforce the subject, to associate topics with students' daily lives, to enhance the retention of learning, and to provide effective and entertaining Turkish instruction. Turkish teachers stated that they used the educational games such as word games, card and board games, verbal intelligence games, story cards, proverb and idiom cards, story cubes, taboo game and educational games, and pantomime. The educational games are considered as necessary to develop all four language skills. Turkish teachers stated that they are competent enough to both use and create the educational games since they receive needed training, conduct researches, follow the current information, and prepare TUBITAK projects.
\end{abstract}

Keywords: Game-Based Learning, Educational Game, Turkish Lesson, Turkish Teachers of Science and Art Center.

\section{GİRIŞ}

Bebeklikten çocukluk dönemine geçen ve sosyalleşmeye başlayan bireyin ögrrenmesinde en önemli etkinliklerden biri oyundur. Hem kendi kendine hem de ailesi ve çevresiyle oynadığ sağlarken aynı zamanda onun öğrenmesine de yardımcı olur. Oyun, çocuğun isteğiyle içinde yer aldığı, kendisi ile çevresini anlamasını, onlarla iletişim ve etkileşim kurmasını sağlayan, kurallı ya da kuralsız yapılan hem eğlendirici hem de eğitici-öğretici etkinliktir. Oyun, çocukluğun her döneminde vardır. Aile ve yakın çevre ile başlayan oyunlar, okul döneminde arkadaşlarla sınıfta veya okul bahçesinde, çevresinde yapılan etkinliğe dönüşür. Çocuklar kendi istekleri ile bu 
etkinlikleri yaparken öğretmenler de çocuğun öğrenmesinde ve eğlenmesinde önemli yere sahip olan oyunları, derslerine dahil ederler. Öğrencilerin gelişim ve ihtiyaçlarına uygun, dersin kazanımlarını ve öğretilmek istenen davranışları kazandırmayı sağlayan oyunları derslerinde kullanan öğretmenler, öğrencilerini hem eğlendirir hem de onların sergilemesini beklediği istendik davranışın oluşmasını sağlar. Çocuğun aktif olduğu, sosyalleștiği, eğlendiği, öğrendiği oyunlardan yararlanarak eğitim öğretim yapılması oyun temelli öğrenme yöntemini değerli kılmıştır. Okul öncesi dönemde eğitim hayatına başlayan çocuğun bütün eğitim hayatı boyunca oyunlardan oluşan öğretim yöntemi ile karşılaşması kaçınılmazdır. Oyun temelli öğretimin kullanıldığı ve birçok kazanımın bu yöntemle verildiği Türkçe dersleri de bunlardan biridir. Türkçe öğretmenleri, öğrencilerine dil bilinci kazandırmak, dil becerilerini öğretmek, Türk kültürüne ait birçok unsuru vermek için oyun temelli öğretimden yararlanabilir. Türkçe öğretmenlerinin oyun temelli öğretim yöntemini derslerinde kullanıp kullanmama durumu, ne sıklıkta kullandığı, hangi oyunlardan yararlandığı merak edilen konulardandır. $\mathrm{Bu}$ durum yapılan araştırmanın amaçlarını oluşturmaktadır. Çocuğun hayatında ve eğitiminde önemli yere sahip olan oyunu bir yöntem olarak kullanan Türkçe öğretmenlerinin görüşlerinin alındığı bu araştırmanın alana katkı sağlayacağı düşünülmektedir.

\section{Oyun}

Çocuğun aktif olarak yer aldığı, kalıcı öğrenmeyi sağlayan ve gerçek yaşamında her zaman var olan oyunun pek çok tanımı vardır: Oyun, çocukların bıkmadan yaptıkları belirli becerileri geliştirici ve pekiştirici bir araç (Özdemir ve Ramazan, 2012: 2); eğlence ve öğrenmek için en önemli kaynak (Ayan ve Dündar, 2009: 63); gerçek dünya ile çocukların hayal dünyalarını bağlayan köprü (Güngörmüş, 2017: 17) kuralları önceden belirlenmiş mücadele, rekabet ve performansa dayalı yarışma, yetenek ve zekâ geliştiren, iyi vakit geçirmeye yarayan eğlence (TDK, 2020) olarak tanımlanmıştır. Oyun yaşamın her döneminde farklı ihtiyaçlara göre şekil değiştirerek yer alır. Oyunların özelliklerini şöyle sıralayabiliriz:

- Hayatın her dönemine hitap eder.

- Oyunlar gönüllü oynanır.

- Çocukların öğrenmeye olan içsel motivasyonunu geliştirir.

- Oyuncular aktiftir ve özgürce oynarlar.

- Enerjilerini oyunla rahatlikla atarlar.

- Kurallı ya da kuralsız olabilirler ve kurallı olanların kuralları önceden belirlidir.

- Çocuklarda sosyalleşmeyi sağlar, deneyim oluşturur.

- Çocukların yetişkinlerin rolüne girmesini ve hayatı anlamlandırmasını sağlar. 
- Öğrenmede eğlence ve kaliteli vakit sağlar.

- Çocukların yeteneklerine göre gelişim imkânı sağlar.

- İhtiyaçlara göre şekillendirilir, geliştirilir ve değiştirilir.

- Soyut kavramları somutlaştırarak daha anlaş1lır kılar.

- Mücadele, performans ve rekabet içerir.

- Kalıcı öğrenmeyi sağlar.

- Kayg1, stres, üzüntü gibi olumsuz durumlardan kurtulmalarına yardımc1 olur.

- Dikkat sürelerini arttırır.

- Çocuklarda heyecan ve mutluluk uyandirır.

- Hoşgörülü olma ve iletişim kurmaya yardımcı olur.

- Empati, özgüven, eleştirel düşünme ve yaratıcılıkları gelişir.

- Yardımlaşma, paylaşma, saygı duyma, kurallara uyma, empati gibi değerleri kazandırır.

- Estetik açıdan gelişmelerini sağlar.

- Çocukların hayatı anlamlandırmasına yardımcı olur (Öğretir, 2008: 94; Özer vd., 2006: 54; Pehlivan, 2005: 28; Ayan ve Dündar, 2009: 63; Arkün Kocadere vd., 2016: 397; Koçyiğit vd., 2007: 324; Çoban ve Nacar, 2015: 37; Mangır ve Aktaş, 1993: 14; Russ, 2003: 291).

\section{Oyun Temelli Öğrenmenin Türkçe Eğitimindeki Yeri}

Birçok özelliğe ve yarara sahip oyunların eğitim öğretimde de önemli bir yeri vardır. Oyunlardan sadece okul öncesi dönemde değil eğitim öğretimin yapıldığ 1 dönemlerde de yararlanılmas1 uygundur (Henniger, 2005: 38). Yapılandırmac1 yaklaşımın benimsendiği Türk Eğitim Sistemi'nde öğrencinin aktif olduğu, yaparak yaşayarak öğrenmenin sağlandığ 1 bir eğitim öğretim ortamı oluşturulmaya çalışılmaktadır (Yurdakul, 2015: 39). Millî Eğitim Bakanlığı; bilgiyi üreten ve bu bilgiyi hayatta işlevsel olarak kullanabilen, problem çözebilen, eleştirel düşünen, girişimci, kararlı, iletişim becerilerine sahip, empati yapabilen, topluma ve kültüre katkı sağlayan vb. niteliklerdeki bir birey yetiştirmeyi amaçlar. Türkçe Dersi Öğretim Programı'nda dinleme, konuşma, okuma ve yazma becerilerinin tek bir öğrenme-öğretme yaklaşımı ile verilemeyeceği, farklı öğretim yöntem ve tekniklerinin bir arada dengeli şekilde kullanılması gerektiği vurgulanır. Aynı zamanda öğrencilerin öğrenme-öğretme sürecinde aktif katılımları ve kendi öğrenmelerinin sorumluluğunu almalarına yönelik teşvik edilmesi gerektiği belirtilir. Öğrencilerin Türkçe dersi kapsamında öğrendiklerini içinde yaşadıkları sosyokültürel ve çevresel durumlarla ilişkilendirmeleri, aktif olmaları bunun için de bu tarz etkinlik ve çalışmalara yer verilmesi gerektiği üzerinde önemle durulur. Çünkü bu tarz etkinlikler, hem öğrencide öğrenmeye karşı olumlu tutum geliştirir hem de öğrenme anlamlı ve kalıcı olur (MEB, 2019: 5). Bu amaçlara oyunun eğitimde kullanılması ile 
ulaşılabilir. Oyunu temel alan ve odağına koyarak öğretimin yapıldığ olan oyun temelli öğrenme yaklaşımı Türkçe eğitiminde de yerini almıştır. Oyun temelli öğrenme yöntemi öğrencinin öğrenmesine ve gelişmesine katkı sağlar ve önemli yere sahiptir. Tüm derslerin olduğu gibi Türkçe dersinin de eğlenceli geçmesini, konuların aktif şekilde öğrenilmesini sağlar. Öğrenciler birlikte hareket ederek sosyalleşir, iş birliği hâlinde öğrenme gerçekleşir. Türkçe dersine ilgi artar, içsel motivasyon yükselir ve akademik başarı artar. Oyun temelli öğrenmenin Türkçenin eğitim ve öğretimine sağladığı katkılar aşağıda sıralanmıștır:

- Öğrenciler kelimeleri doğru telaffuz etmeyi öğrenirler.

- Öğrencilerin pratik konuşma becerileri gelişir.

- Etkili iletişim kurma becerileri gelişir.

- Ezber yetenekleri ve kelime hazineleri gelişir.

- Kavram, terim veya kelimeleri hafızada tutma, eşleştirme, sınıflandırma gibi becerileri kazanırlar.

- Düşünme, algılama, zihinsel planlama gibi soyut becerileri gelişir.

- Oyunlarda yer alan benzetim ve taklit unsurları öğrencilerin taklit yeteneklerini geliştirir. Derste yapılan psikodramalar, temsiller öğrenciyi gerçek yaşamdaki rolüne hazırlar ve öğrencinin davranışlarını şekillendirmesini sağlar.

- Derste öğrendikleri özellikle dil bilgisi konularını pratikte kullanmayı öğrenirler.

- Adalet, dostluk, dürüstlük, öz denetim, sabır, saygı, sevgi, sorumluluk, vatanseverlik, yardımseverlik gibi Türkçe Öğretim Programı'nda yer alan kök değerleri kazanırlar.

- Grup hâlinde oynanan oyunlarda anlama ve anlatma becerileri gelişir.

- El yazısı yazma konusunda sıkıntı yaşayan çocukların el hareketlerini ve parmak kaslarını geliştirmede oyunlar yararlı olabilir.

- İş̧irlikli öğrenme gerçekleşir, çocukların empati kurma, hoşgörülü olma gibi değerleri kazanmasına yardımcı olur.

- Derste dikkat süreleri artar.

- $\quad$ Problem çözme, eleştirel düşünme, karar verme, yaratıcı düşünme gibi üst düzey becerileri kazanmasına yardımcı olur.

- Daha fazla duyuya hitap ettiği için kolay ve kalıcı öğrenmeyi sağlar.

- Derste öğrenilen konuların tekrar edilmesini ve bilgilerin pekişmesini sağlar.

- Öğrenci aktif olarak derste yer alacağından öğretmen bireysel olarak onu değerlendirir, kazanıma ulaşıp ulaşmadığını varsa eksiklerini görür ve bu sayede değerlendirme bireye özgü yapılır. Bilişsel, duyuşsal ve psikomotor öğrenmeleri rahatlıkla ölçme değerlendirme yapma olanağı sağlar.

- Öğretmene sınıf yönetimi konusunda yardımcı olur.

- Öğretmen ve öğrenci iletişimini güçlendirir. 
- Okuma alışkanlığı kazandırmada da yardımcı olabilir (Ulutaş, 2011: 32; Karabacak, 1996: 23; Öztemiz ve Önal, 2013: 65; Çağdaş ve Şahin Seçer, 2002: 45; Gülhan, 2012: 64; Pehlivan, 2005: 38; Yavuzer, 2017: 70; Demirel, 2007: $52)$.

Öğretmenlerin derste yararlandığ etmesi gereken durumlar vardır. Oyunlar dersin kazanımına ve konusuna uygun, bütün öğrencilerin rahatlıkla anlayabileceği ve uygulayabileceği, öğrencilerin yaş seviyesi ve gelişim özelliklerine göre seçilmelidir. Ayrıca oyunun nerede (sınıf veya dışarıda), ne zaman (dersin hangi aşamasında), ne kadar sürede, nasıl (bireysel ya da grup) oynanacağı hangi materyallerin kullanılacağı belirlenmeli, oyunun eğlenceli olmasına dikkat edilmelidir. Öğretmen oyun esnasında hem danışman, hem yönetmen hem de oyuncu olabilir. Oyun öğrencilerin ön bilgilerini harekete geçirerek yeni bilgilerin yapılandırılmasına ve kullanılmasına yardımcı olmalıdır. Bu sayede ders eğlenceli, öğrenciler aktif, öğretilen bilgiler de kalıcı olabilir (Özyürek ve Çavuş, 2016: 2157).

Genel anlamda eğitimde özel anlamda Türkçe eğitimi ve öğretiminde aktif ve kalıcı öğrenmeyi sağlayan oyun temelli öğrenme tekniğini kullanacak olanlar Türkçe öğretmenleridir. Türkçe öğretmenlerinin oyun temelli öğrenme hakkında neler düşündükleri, bu yönteme derslerinde ne kadar ve nasıl yer verdiklerinin bilinmesi Türkçe eğitimi ve öğretimi açısından önemlidir. Bu çalışmada temelde bu bilgilere ulaşmak amaçlanmakta ve bu çalışmanın alana katkı sağlayacağ 1 düşünülmektedir.

\section{Araştırmanın Amacı}

$\mathrm{Bu}$ araştırma, Bilim ve Sanat Merkezlerinde (BILLSEM) çalışan Türkçe öğretmenlerinin eğitsel oyuna yönelik görüşlerini belirlemek ve bu görüşlerden hareketle Türkçe derslerinde eğitsel oyunun yeri ve derse katkısı ile ilgili değerlendirme yapmak amacıyla yapılmıştır. $\mathrm{Bu}$ amaca ulaşmak için katılımcılara aşağıdaki sorular yöneltilmiştir:

- Sizce çocuklar için Türkçe dersinde en etkili öğretim yöntemi hangisidir?

- En sık hangi öğretim yöntemini kullanmayı tercih edersiniz? Neden?

- Size göre "eğitsel oyun" nedir?

- Türkçe dersinde eğitsel oyunun kullanılması gerekli midir? Neden?

- Siz eğitsel oyunu öğretim yöntemi olarak kullanıyor musunuz? Neden?

- Türkçe derslerinde eğitsel oyunu kullanma sıklığınız nedir?

- Hangi sinıflarda / gruplarda daha çok eğitsel oyun kullanırsınız?

- Hangi tür eğitsel oyunlara daha fazla yer veriyorsunuz? Örnek veriniz.

- Eğitsel oyunu hangi tür konuların öğretiminde kullanmak daha uygundur? Neden? 
- Eğitsel oyunlar, Türkçe eğitiminde hangi becerileri (dinleme, konuşma, okuma, yazma) kazandırmada daha etkilidir?

- Eğitsel oyunları etkili şekilde Türkçe derslerinde kullanabiliyor musunuz? Buna etki eden olumlu ve olumsuz faktörler nelerdir?

- Öğretimde eğitsel oyunun kullanılmasının faydaları neler olabilir? (Öğretmen ve öğrenci açısından)

- Öğretimde eğitsel oyunun kullanılması öğretmenin sınıf (grup) yönetimini etkiler mi? Neden?

- Kendinizi eğitsel oyunu öğretim yöntemi olarak kullanma konusunda yeterli hissediyor musunuz? Bu konuda bilgi gereksinimi duyuyor musunuz?

- Eğitsel oyunları öğrenmek veya kullanmak için yararlandığınız kitap, web sitesi, uygulama vb. var mı? Varsa adlarını söyleyiniz.

- Dersinizde kullanmak üzere tasarladığınız eğitsel oyun, yayın vb. var mı? $\mathrm{Bu}$ konuda özel çalışmalar yapıyor musunuz?

\section{YÖNTEM}

Bu bölümde araştırmanın modeli, araştırmanın amacı, katılımcıları, verilerin toplanması ve analizi ile ilgili bilgiler verilmiştir.

\section{Araştırma Modeli}

$\mathrm{Bu}$ araştırma nitel olarak tasarlanmıştır. Nitel araştırma; görüşme, gözlem ve doküman analizi ile verilerin toplanmasına dayanan, olay veya algıları doğal ortamda gerçekçi bir şekilde ele alan nitel bir araştırma sürecidir. Sözlü iletişim yoluyla veri toplama tekniği olan görüşme, bireylerin çeşitli konularda sahip oldukları tutum ve davranışlar hakkında bilgi almak ve bu davranış ve tutumlarının sebeplerini öğrenmek için kullanılır (Yıldırım ve Şimşek, 2013: 45).

\section{Katılımcılar}

Araştırmanın katılımcıları, çalışmanın amacına uygun olarak Bilim ve Sanat Merkezlerinde görev yapan Türkçe öğretmenlerinden seçilmiştir. Veriler Türkiye'nin farklı illerinde çalışan dört kadın, dört erkek Türkçe öğretmeninden toplanmıştır. Katılımcıların dördü yüksek lisans, dördü doktora mezunudur. Katılımcılar, eğitsel oyunları derslerinde kullanan ve bu konuda uzman olan Türkçe öğretmenleridir.

\section{Verilerin Toplanması ve Analizi}

Araştırmada ölçme araçlarının uygulanması, verilerin toplanması için gerekli olan etik izin, Karamanoğlu Mehmetbey Üniversitesi Rektörlüğü Bilimsel Araştırma ve Yayın Etik Kurulundan alınmıştır (22.02.2021 tarih / E-6162). Araştırmanın verileri görüşme tekniği kullanılarak toplanmıştır. Açık uçlu 
görüşme formu araştırmacı tarafından hazırlanmış, iki alan uzmanına sunulmuş ve görüssler doğrultusunda forma son şekli verilmiştir. Bu form önce Bilim ve Sanat Merkezlerinde görev yapan iki Türkçe öğretmenine uygulanmış, uygulama sonunda bazı ifadeler değiştirilmiş, konu bütünlüğü sağlanmış ve kullanılır hâle getirilmiştir. Görüşmeler telefonla yapılmış, verilen cevaplar kaydedilmiştir.

Toplanan verilerin analizi içerik analizi ile yapılmıştır. Görüşme sorularından hareketle veriler kategorilere ayrılmış, araştırmanın amacına uygun başlıklar oluşturulmuştur. Araştırmanın geçerliği için araştırılan konunun en doğal ve yansız ortamda elde edilmesine çalışılmıştır. Tarafsızlığın sağlanması için araştırmacı ile BİLSEM tecrübesi olan bir alan uzmanı, cevapları incelemiş ve çözümlemiştir. Araştırmacıların belirledikleri başlıklar karşılaştırılıp birleştirilmiştir. Başlıklar oluşturulduktan sonra asıl verilerle karşılaştırılmış ve kontrol edilmiştir. Araştırmanın güvenirliği için kodlar arası uyuma bakılmıştır. Kodlayıcıların görüş birliği yüzdesi Miles ve Huberman'ın (2015: 64) Güvenirlik $=$ Görüş birliği sayısı / Toplam görüş birliği + Görüş ayrıllğ1 sayısı şeklindeki güvenirlik formülü ile hesaplanmıştır. Buna göre güvenirliğin yüzdesi 89 bulunmuştur. Alıntıların aktarılmasında öğretmenler Ö1, Ö2, Ö3 (öğretmen 3)... şeklinde verilmiştir.

\section{BULGULAR}

Araştırmada katılımcılarla yapılan görüşmeler sonucu elde edilen bulgular kodlanan başlıklar altında aşağıda sıralanmıştır:

\section{Türkçe Dersindeki En Etkili ve Sık Kullanılan Yöntemler}

Türkçe öğretmenleri Türkçe derslerindeki en etkili yöntemi belirlemek için öğretmenin, etkinliğin, temanın, konunun, öğrencinin uygunluğuna dikkat edilmesi gerektiğini vurgulamışlardır. Türkçe öğretmenleri, öğrencilerin bizzat öğrenme sürecinin içerisinde olduğu yaparak yaşayarak öğrenme modelinin Türkçe derslerinde en etkili yöntem olduğunu belirtmişlerdir. Buluş yoluyla öğrenme, gösterip yaptırma, beyin firtınası, tartışma, problem çözme, soru cevap, oyunlaştırma Türkçe öğretmenlerince Türkçe derslerinde en sık kullanılan yöntemlerdendir.

Ö1: "Yaparak yaşayarak öğrenme, buluş yoluyla öğrenme ve beyin fırtınası yöntemlerini kullanıyorum daha çok."

Ö2: “Öğrenci kendini ne kadar etkinliğin içinde hissediyorsa yöntem o kadar etkili oluyor. Bunun için buluş yolu, yaparak yaşayarak, gösterip yaptırma öncelikli olmalı. Bir konunun sunumunda soru cevapla başlayıp konuya göre devam ediyorum.” 
Ö3: "Çocukların bizzat öğrenme sürecinin içerisinde olduğu yaparak yaşayarak öğrenme modelinin en etkin öğrenme yöntemi olduğunu düşünüyorum. Bir konunun sunumunda öncelikle soru cevap yöntemiyle başlayıp öğrencilerin ön bilgilerini harekete geçirmenin gerekli olduğunu düşünüyorum. Ardından diğer yöntemler (düz anlatım, beyin firtınası vb.) kullanılabilir. Soru cevap yönteminin sınıfın derse olan ilgisini artırmasının yanı sıra öğretmenin öğrencilerin hazır bulunuşlukları hakkında fikir sahibi olmasını sağlaması açısından önemli olduğunu düşünüyorum."

Ö4: “Öğrencilerin öğrenme sürecinin bizzat içerisinde yer aldıkları yaparak yaşayarak öğrenme gibi yöntem ve tekniklerin daha uygun olduğunu düşünüyorum. Özel yetenekli öğrencilerle grup çalışmaları yaptığımız için gösterip yaptırma, yaparak yaşayarak öğrenme, buluş yoluyla öğrenme gibi yöntemleri daha çok tercih ediyorum.”

Ö5: "Bireysel farklılıklara göre ve hazırbulunuşluklarına göre değişmektedir. Hatta öğretmenin almış olduğu eğitim bile bunda etkili. Hangi beceri alanlarında kendisini geliştirdiyse öğretmen o alanın yöntem ve teknikleri üzerinden ilerliyor. Buluş yoluyla öğretim, öğrencilerin hem hayal güçlerini hem de yaratıcılıklarını ortaya çıkartıyor."

Ö6: "Bence öğretmenin, etkinliğin, temanın ve konunun uygunluğuna göre tüm yöntemler en etkili yöntemdir. Soru cevap ve beyin fırtınasından sıkça yararlaniyorum."

Ö7: "Aslında en etkili yöntem şudur demek doğru değil, amaca, içeriğe, ortama göre yöntemler değişebilir, en etkilileri tartışma, problem çözme ve oyunlaştırma yöntemidir, diyebilirim. Bir konunun sunumunda en çok kullandığım yöntem tartışma diyebilirim, bu yöntemle öğrenciler üst düzey düşünürler, analiz etme ve değerlendirme becerileri gelişir."

Ö8: "Uygulamaya dönük yöntemler, sorgulayıc1 öğretim yöntemi, oyun tabanlı öğrenme yöntemi en etkililerdir. Bilginin beceriye dönüşüp dönüşmediğini anlamak için çocukların kazanımı deneyimlemesini isterim çünkü masal yazmadan masal türü kavratılmaz. Bilginin pratiğe dönüştügü durumlarda etkin öğrenme gerçekleşir."

\section{Türkçe Öğretmenlerinin Eğitsel Oyun Algıları}

Türkçe öğretmenlerine göre oyun, öğrencinin eğlenmesine ve hoşça vakit geçirmesine neden olan her şeydir. Türkçe öğretmenleri eğitsel oyunu belirli kuralları olan, yetenek ve zekâ geliştiren, eğlendirirken öğreten eğlenceler bütünü olarak tanımlamıştır. 
Ö1: "Yetenek ve zekâ geliştiren, belirli kuralları olan, çocukların ilgisini çeken her şey oyun olabilir."

Ö2: "Oyun çocuğun gelişimi için yapılan eğlenceli etkinlikler bütünüdür."

Ö3: “Çocuğun yaparken keyif aldığı her şey oyun olarak düşünülebilir.”

Ö4: "Bana göre oyun kendi içerisinde belirli kuralları olan bir eğlence sistemidir."

Ö5: "Eğitim amaçlı kullanılan bir düzenektir. Bu düzeneğin kuralları önceden oluşturulabilir veya birlikte karar verilerek de oluşturulabilir."

Ö7: “Oyun çocuğun iç dünyasını ortaya çıkardığı, özgürce hareket ettiği, örtük olarak öğrendiği zamandır."

Ö8: “Oyun, sadece çocukluğa özgü bir kavram değildir. Hayatın her evresinde vardır. Farklı isimlerle anılıp farklı kurallara sahip olsalar da bütün oyunlar insanların keyifli vakit geçirmesine hizmet ederler. Eğitimde oyun ise bilgiyi eğlenceli hâle getiren, öğrencinin sosyal, fiziksel, zihinsel, ruhsal gelişimine katkıda bulunan zevkli uygulamalardır."

\section{Eğitsel Oyunların Türkçe Derslerinde Gereklilik Durumu}

Türkçe öğretmenleri eğitsel oyunun tüm derslerde olduğu gibi Türkçe derslerinde de gerekli olduğunu vurgulamış, gerekçelerini de sunarak eğitsel oyunları hangi amaçla kullandıklarına açıklık getirmişlerdir. Oyunlarla iç içe olan öğrencilerin hem Türkçe dersine karşı motivasyonlarının ve odaklanmalarının artacağı hem de oyunların Türkçe dersini etkili, kalıcı, eğlenceli hâle getireceğini düşündüklerinden eğitsel oyunları gerekli görmüşlerdir.

Ö1: "Gereklidir. Oyun sayesinde dersler daha verimli olabilir. Oyunu öğretim yöntemi olarak kullanıyorum. Derslerimin öğrencilerim tarafından ilgi çekici olmasını ve dersteki dinamizmin sürekliliği için.”

Ö2: "Bence çok gereklidir. Oyun yoluyla birçok konunun kalıcı öğretimi sağlanabilir. Öğrenciler oyunla örülü etkinliklerden çok keyif alıyorlar. Derslerimin daha eğlenceli, öğrenciler açısından verimli olması için eğitsel oyunları kullanıyorum."

Ö3: "Evet, gereklidir. Oyunlar yoluyla Türkçe dersinin bazı konularının kalıcı olarak öğretimi sağlanabilir. Bu sayede öğrencilerimin Türkçe dersine daha fazla ilgi gösterdiklerini ve kalıcı öğrenmeler sağladıklarını gözlemliyorum. Öğrencilerin ilgi ve motivasyonlarını arttırma, işbirlikli çalışma kültürünün 
gruplarda yerleşmesi, eğlenirken öğrenmenin gerçekleşmesi gibi konularda oyunlardan yararlanıyorum."

Ö4: "Sadece Türkçe dersinde değil, tüm derslerde oyunlardan eğitim amaçlı yararlanılması gerektiğini düşünüyorum. Öğrencilerin ilgi ve motivasyonlarını arttırmak için oyunlardan yararlanıyorum."

Ö5: "Eğlenme amaçlı kullanılmasından ziyade eğitim amaçlı kullanılması gerekir. Ders eğlenmek midir, yoksa yaşantı oluşturmak mıdır? Bu soruya vereceğimiz cevapla şekillenebilir. Hayatın kendisiyse ders oyun yaşantı oluşturmalıdır. Bir işin işlem basamaklarını ortaya çıkartmada eğitsel oyunlar çok faydalı oluyor. Tanışma ve kuralları olan belli bir düzeneğin anlaşılması amacıyla çok kullanırım. Ayrıca bilgileri doğrudan vermektense sezdirmenin en kolay yolu eğitsel oyunlar."

Ö6: "Elbette gereklidir. Bu sayede dersler daha verimli olur. Derslerimin ilgi çekici olması bakımından eğitsel oyunları kullanıyorum. Konunun uygunluğuyla oyun bütünleşirse öğrenmede kalıcılık kaçınılmaz oluyor. Konuya ilgi çekmek ve öğrencilerin ders boyunca ilgilerini yüksek tutmak için oyunlardan faydalaniyorum."

Ö7: “Tüm derslerde kullanılmalıdır. Oyun oynarken öğrenilenler kalıcı olur, çocuklar eğlenirken öğrenirler, kendilerini rahatça ifade edebilirler. Özellikle küçük yaş gruplarında daha etkili, dikkat çekici. Öğrenciler birçok konuyu sıkılmadan, eğlenerek ve kalıcı olarak öğrenirler, birçok konuyu somutlaştırmış oluruz. Genellikle öğretim yöntemi olarak, bazen öğrencilerin dikkatini çekmek için eğitsel oyunlardan yararlanıyorum."

Ö8: "Oyun bütün derslerde gereklidir. Oyunu sevmeyen çocuk yoktur. Çocukların sevdiği uygulamaları sınıf içine taşımak ve onlardan yararlanmasını bilmek gerekir. Çocukların öğrenirken mutlu olmaları beni de mutlu ediyor. Böyle bir durumda eğitim neşeli bir sürece dönüşüyor. Kazanımları kavratmak amaciyla oyunları kullanıorum."

\section{Eğitsel Oyunların Türkçe Derslerinde Kullanılma Sıklığı}

Türkçe öğretmenleri, 3, 4, 5, 6, 7, 8 ve 9. sınıflardaki derslerinde eğitsel dijital oyunları kullandıklarını belirtmişlerdir. Katılımcılar arasında beş ya da altı saatlik haftalık Türkçe ders saatinin bir ya da iki saatini eğitsel oyunlar için kullandıklarını belirtenler olduğu gibi ihtiyaç duyduğunda konuya bağlı olarak kullanan öğretmenler de vardır.

Ö1: "Her 5 dersten birinde oyuna yer veriyorum.” 
Ö2: “Ayda bir iki defa derslerde yer veririm.”

Ö3: "Her bir grup için ayda en az bir oyunlu etkinlik gerçekleştiriyorum."

Ö4: “Ortalama olarak ayda bir diyebilirim.”

Ö5: "Ders süresinin yüzde yirmi-yirmi beşinde eğitsel oyunları kullanırım."

Ö6: "Haftada bir eğitsel oyunları derste kullanırım."

Ö7: "Genellikle kullanırım, içerikle bağdaştırırım."

Ö8: "Konuya bağlı olarak değişmektedir."

Türkçe öğretmenleri, eğitsel oyunların derslerinde etkili olduğunu, öğrencileri motive ettiğini, grup içi iş birliğinin ve sınıf içi iletişimin gelişimine katkıda bulunduğunu belirtmişler bununla birlikte oyunların derslerde kullanımının bazı olumsuzluklara da neden olabildiğini vurgulamışlardır.

Eğitsel oyunların derslerde etkili olup olmamasını; BİLSEM Türkçe Öğretim Programının esnek olup olmaması, öğretmen ve öğrencinin hazır bulunuşluğu, konuların uygunluğu ve grupların kalabalık olup olmama durumu etkilemektedir.

Ö1: "Eğitsel oyunların derslerde etkili olup olmamasını birçok faktör olumlu, olumsuz etkiler. Konunun yapısı, öğrencinin hazır bulunuşluğu gibi.”

Ö2: "Etkili bir şekilde kullanılması için konuya uygun oyun seçilmesi gerekir."

Ö3: "Derslerimde etkili bir şekilde kullanabiliyorum. En çok etki; program ve müfredatın bu konuda yetersiz kalması olabiliyor. Bununla birlikte BİLSEM öğretmenlerinin bazı konularda esnek davranabilmeleri oyunlara yeterli ve dengeli düzeyde yer verilmesine imkân tanıyabiliyor.”

Ö4: "BİLSEM'de grup çalışmaları yaptığımız için grup içi iş birliği, iletişim, motivasyon, ölçülü rekabet gibi hususların gelişiminde oyunların büyük etkisi oluyor. Eğitsel oyunları etkili kullandığımı düşünüyorum.”

Ö5: "Grup içi uyum iyi olduğunda kullanımı kolay oluyor. Grup dinamikleri oyunun etkililiğini çok fazla etkiliyor."

Ö6: "Olumsuzluk şöyle ki programın buna müsaade etmesi ve etkinliklerin buna göre yapılandırılması gerekiyor. Ama ben buna rağmen esnek davranıyorum ve oyunlardan yararlanıyorum." 
Ö7: "BİLSEM'de öğrenci grupları sayıca az olduğu için oyunları etkili kullanabiliyorum, kalabalık sinıflarda uygulamada sorunlar olabilir, sinıf yönetimi konusunda.”

Ö8: "Sınıf mevcudu çok önemli. Kalabalık sınıflarda oyun oynansa bile etkinlik pek verimli olmuyor. 3-7 kişi gayet iyi. Ayrıca sınıf içinde harekete dayalı oyunlar yerine zihinsel becerileri geliştirmeye dayalı oyunlara yer verilmeli."

\section{Türkçe Derslerinde Tercih Edilen Eğitsel Oyunlar}

Türkçe öğretmenleri kelime oyunları, masaüstü oyunlarının Türkçe dersine uygun olanlarını, kart ve kutu oyunları, sözel zekâ oyunları, hikâye kartları, drama görselleri, atasözü ve deyim kartları, hikâye küpleri, tabu, web 2 araçları, pandomim gibi eğitsel oyunlara derslerinde yer verdiklerini belirtmişlerdir.

Ö1: "Genel olarak kelime çalışmalarında kelime oyunlarından ve bazı geleneksel oyunlardan yararlanırım."

Ö2: “Oyun atölyemiz var BİLSEM'de. Oradaki masaüstü oyunların tamamını kullaniyoruz."

Ö3: "Kart ve kutu oyunlarını daha çok kullanıyorum.”

Ö4: "Board games denilen masaüstü oyunlarının Türkçe dersine uygun olanlarını kullanıyorum."

Ö5: "Kutu oyunları ve zekâ oyunlarına yer veriyorum. Hikâye kartları, drama görselleri vb.”

Ö6: "Zekâ oyunlarına daha çok yer veriyorum.”

Ö7: "Sözel zekâ oyunları ve kutu oyunları, atasözü deyim kartları, hikâye küpleri, tabu, web 2 araçları."

Ö8: "Kelime oyunları, sözel zekâ oyunları, pandomim gibi eğitsel oyunlardan yararlaniyorum."

\section{Eğitsel Oyunların Türkçe Dersi Beceri ve Konularına Göre Kullanımı}

Katılımcılar, eğitsel oyunların Türkçe dersinin dinleme, konuşma, okuma, yazma gibi dil becerilerini kazandırmada ve soyut kavram ve kuralları içeren dil bilgisi öğretiminde önemli yere sahip olduğunu vurgulamışlardır. Eğitsel oyunların her becerinin kazanımına ve her konuya uygun şekilde seçilip kullanılabileceğini, bu konuda herhangi bir sıkıntı yaşamadıklarını 
belirtmişlerdir. Türkçe öğretmenleri Türkçe dersinin bir bütün olarak işlenmesini, becerilerin bir arada verilmesi gerektiğini vurgulamışlardır. Eğitsel oyunların temin edilirse her konuyu vermede etkili olacağını söyleseler de özellikle kelime ve kavram öğretiminde, söz varlığını zenginleştirmede, hazırlıksız konuşma, yaratıcı düşünme becerilerini geliştirmede, yaratıcı yazma becerilerinde kullanıldığını belirtmişlerdir. Ayrıca eğitsel oyunların, dil bilgisi öğretiminde özellikle soyut konuların anlaşılması ve kalıcı hâle gelmesinde etkili olduğu belirtilmiştir.

Ö1: “Tüm konularda oyunlardan faydalanmak mümkündür. Bütün becerilere temas eden oyunlar var. Eğitmen hangi beceriyi geliştirmek isterse ona göre bir oyun seçebilir.”

Ö2: "Bence tüm konularda oyun kullanılır. Konunun uygun olması da önemli tabii. Okuma, yazma, konuşma, dinleme / izleme yani tüm becerilerde oyunla ögretimin faydası olur.

Ö3: “Öğrencilerin nispeten daha az ilgi gösterdikleri konuların (Örn. dil bilgisi konuları) öğretiminde oyunların kullanılmasının daha yararlı olduğunu düşünüyorum. Her bir becerinin geliştirilmesine yönelik oyunlar gerçekleştirilebiliyor. Öğretmen hangi beceriyi geliştirmek istiyorsa öğrencilerine buna yönelik oyunlar oynatabilir."

Ö4: "Tüm konuların öğretiminde oyunlardan faydalanılabilir. Şöyle ki bu konunun ve oyunun birbirine olan uyumuyla da doğrudan ilgili."

Ö5: "Metin türü olarak masal, hikâye ve fabl öğretiminde kullanıyorum. Oyun yoluyla bu türlerin özellikleri daha kolay aktarıllyor veya seziliyor."

Ö6: "Eğitsel oyunlar söz varlığının gelişmesinde oldukça etkilidir. Bunun yanında farklı oyunların farklı becerileri geliştirdiği de muhakkak."

Ö7: “Temel dil becerilerini bir bütün olarak düşünmeliyiz, aslında oyunlar her beceriye hitap eder, daha çok konuşma olabilir. Çoğu konu oyunlaştırılabilir. Kelime ve kavram öğretiminde, hazırlıksız konuşma, yaratıcı düşünme becerileri, yaratıcı yazmada kullanılabilir. Daha çok soyut konuları somutlaştırmak için uygun olabilir. Kalıcı öğrenmeler için. Örneğin öğrenci bir atasözünün resfebesini hazırladığında ve anlamını pekiştirdiğinde bir daha unutmayacaktır."

Ö8: "Bütün becerilerde gereklidir. Ben daha çok konuşma, yazma ve dinleme becerilerinin geliştirilmesinde kullanıyorum. Yazma becerilerinin geliştirilmesinde (örn: hikâye, fabl tamamlama oyunu), sözcük hazinesinin zenginleştirilmesinde (scrabble, tabu ve diğer kelime oyunları) eğitsel oyunlardan yararlanıorum.” 


\section{Eğitsel Oyunların Türkçe Dersine Yararları}

Türkçe öğretmenleri eğitsel oyunların sağladığı yararları öğretmen, öğrenci, sınıf yönetimi açısından değerlendirmiştir. Türkçe öğretmenlerine göre eğitsel oyunlar, hem öğretmen için hem de öğrenci için doyum sağlar. Derslere katılım fazla olduğundan konuları öğretmek daha kolay, etkili ve eğlenceli olmaktadır. Az ilgi gören, soyut konuların öğretilmesi ve öğrenilmesi kolaylaşır. Öğretmen açısından dersinin ilgi çekici hâle gelmesi, aktardığ sağlaması ve derslerin akıcı bir zeminde ilerlemesi; öğrenci açısından ana dili derslerinin daha verimli geçmesi, eğitsel oyunların sağladığı yararlar içinde sayılmaktadır. Öğretilen konular pekişmekte ve somutlaşmakta ve öğrenilenlerin gerçek yaşama aktarımı kolay olmaktadır. Grup içinde iş birliğini arttırmakta öğrencilerin kurallara uyma, sabretme, öz denetim, empati gibi beceri ve değerleri kazanmalarına yardımcı olmaktadır. Dersler aktif katılımın olduğu bir ortamda işlendiğinden eğitsel oyunlar sınıf yönetimine öğretmen açısından katkı sağlamaktadır.

Türkçe öğretmenleri eğitsel oyunların Türkçe dersine yararlarını sayarken eğitsel oyunların konuya ve sınıf / grup mevcuduna uygunluğuna, öğretmenin rehberliğini iyi düzeyde yapmasına, oyunun bir amaca hizmet etmesine dikkat çekmişlerdir. Bu durumlarda yetersiz olan bir dersin işleniş̧inde sınıf yönetiminin de olumsuz olacağını bildirmişlerdir.

Ö1: "Her iki tarafa da doyum sağlar. Öğretmen de öğrenci de yapılan etkinlikten keyif alır. Grupların yönetimi daha kolay olur.”

Ö2: "Oyunlar sayesinde Türkçe dersinde nispeten az ilgi gören konuların öğretimi eğlenceli hâle getirilebilir. Sağlıklı öğrenmeler gerçekleştirilebilir. Sınıf yönetimi daha rahat olur tabii ama kargaşa ortamı oluşturmamak lazım, oyunlar kuralına göre oynanmalı."

Ö3: “Öğretmen açısından dersinin ilgi çekici hâle gelmesi, aktardığı konularda kalıcılığı sağlaması ve derslerin akıcı bir zeminde ilerlemesi; öğrenci açısından ana dili derslerinin daha verimli geçmesi oyunun başlıca faydaları olarak sıralanabilir. Öğretmenin sınıf (grup) yönetimini etkiler. Oyunlar sayesinde tüm grubun dikkatinin derse çekilmesi grup yönetiminin çok daha kolay olmasını sağlıyor çünkü."

Ö4: "Konuya ilgi çekme, öğrenmede kalıcılık ve verimlilik sağlama bakımından faydalı olduğunu düşünüyorum. Eğitsel oyunlar sınıf yönetimini elbette etkiler çünkü grubun tamamının yapılan çalışmaya katılımı sağlanıyor. Dersler daha akıcı ve işlevsel hâle geliyor." 
Ö5: "Kolay ve hızlı öğrenmenin yanı sıra sezdirmeye daha uygun. Grup dinamiğini arttırıyor. Birlikte hareket etme, sırasını bekleme, öz denetim, empati vb. becerileri kazandırıyor."

Ö6: "Birçok faydası olabilir. En önemlisi öğretiminde zorluk yaşanan konularda kolaylık sağlar. Benim açımdan etkiliyor, sınıf yönetimi daha kolay oluyor.”

Ö7: “Öğretmen açısından öğrencilerin derse etkin katılımı, öğrenci açısından zevkli, eğlenerek, kalıcı öğrenmeyi sağlar. Sınıf kalabalıksa olumsuz etkileyebilir, burada iyi planlama yapılmalı, görev dağılımına dikkat edilmeli."

Ö8: "Aktif katılımdan dolayı hem öğretmen hem de öğrenci süreçten keyif alır. Bilginin kalıcılığı sağlanmış olur. Mutlu geçen süreçler, çocuklar için birer anı değeri taşır. Eğitim etkinliklerine psikolojik bir boyut da katmış olur. Çocuklar ve öğretmenler daha rahat davrandıkları için kişiler arasındaki bağ da güçlenir. Oyun bir amaca hizmet etmeli. Ayrıca öğrencilerin gelişim düzeyine, sınıf mevcuduna uygun olmalı. Öğretmen yönlendirici, düzenleyici, kuralları uygulayıcı olmalıdır. Böyle bir durumda sınıf yönetiminde sıkıntı yaşanmaz. Öğrencilerin oyuna kendini fazla kaptırması, öğretmenin kontrolü sağlayamaması istenmeyen durumlara yol açabilir."

\section{Türkçe Öğretmenlerinin Eğitsel Oyunlara Ulaşma Durumu}

Türkçe öğretmenleri, eğitsel oyunlara ulaşmak için gerek eğitsel oyun kitaplarından gerekse Instagram, Facebook, Youtube gibi sosyal ortamlardan yararlanmaktadır. Bazı Türkçe öğretmenleri ise kendi çalışmalarını öğrencilerin yaşantılarından yola çıkarak hazırladıklarını ya da tasarladıklarını belirtmişlerdir.

Ö1: "İnternette her şeyi bulmak mümkün, bununla ilgili takip ettiğim birkaç Youtube kanalı var."

Ö2: "Instagramda takip ettiğim kişiler var. Etkinlik ve oyun paylaşımı yapiyorlar."

Ö3: "Sosyal medyada takip ettiğim bazı hesaplar var, bu konuda hazırlanmış neredeyse tüm kitaplara da sahip olduğumu söyleyebilirim."

Ö4: "Yayımlanmış makaleler ve tezlerden yararlanıyorum, sosyal medya ve internet sitelerini de takip ediyorum."

Ö5: "Daha çok öğrencilerin kendi yaşantılarından yola çıkıp oyun tasarliyoruz." 
Ö6: "Birçok imkân var. İnternetten epey kitap almıştım bununla ilgili, onlardan yararlanıorum."

Ö7: "Resfebe konusunda internet sitelerinden faydalanıyorum, yaratıcı yazmada storybird, storyjumper gibi uygulamaları kullandım ayrıca birçok kutu oyununu kullanıyorum."

Ö8: "Kendi oyunlarım var, onları kullanıyorum."

\section{Türkçe Öğretmenlerinin Eğitsel Oyunlara Yönelik Yeterlilik Durumu}

Türkçe öğretmenleri hem eğitsel dijital oyunları kullanmada hem de oluşturmada yeterli donanıma sahip olduklarını bunun için eğitim aldıklarını, araştırma yaptıklarını, güncel bilgileri takip ettiklerini, eğitsel oyunlar ile ilgili akademik çalışmalar yaptıklarını, TUBİTAK projeleri hazırladıklarını belirtmişlerdir. Bazı Türkçe öğretmenleri eğitsel oyunların Millî Eğitim Bakanlığ tarafından temin edilmesi gerektiğini, bu oyunlara ulaşamayınca mecburen kendilerinin hazırladıklarını, bu durumun da çok zaman aldığını vurgulamışlardır.

Ö1: "Benim yüksek lisans tezim bu konuyla ilgili, bu yüzden kendimi yeterli hissediyorum. TUBİTAK bölgeye gönderdiğim iki kelime oyunum var.”

Ö2: "Kendimi eğitsel oyunları öğretim yöntemi olarak kullanma konusunda yeterli görüyorum. Sonuçta bu iş için kurulmuş bir atölyemiz var. Şu an üzerinde çalıştığım iki ayrı masaüstü oyun var.”

Ö3: "Kendimi yeterli hissediyorum çünkü bu konuya ilgi duyuyorum. Konuyla ilgili ödüllü TUBİTAK projelerim ve akademik yayınlarım var. Oyun konusunda yerli ve yabancı literatürü sürekli taradığım için bilgi gereksinimi duyduğumu söyleyemem. Tasarladığım bir hafıza kartı oyunu var. Taslak hâlinde olan başka oyunlarım da var. Oyunları tasarlarken özellikle öğrencilerin söz varlığını zenginleştirmeyi ve bazı dil bilgisi konularının kolay öğretimini amaçliyorum."

Ö4: "Bilgi eksikliği hissetmiyorum. Çünkü bu konuda akademik çalışmalar yapıyor, ilgili kaynakları mutlaka alıyorum. Tasarladığım ve TUBİTAK yarışmalarına gönderdiğim projelerim var."

Ö5: "Kendimizin eğitiminden ziyade oyun materyallerine çok fazla ihtiyaç var. Bu materyaller olmayınca kendimiz üretiyoruz. Ürettiklerimiz de ciddi zaman alıyor fakat ihtiyacı karşılıyor. Ülke genelinde kullanılacak hâlde bakanlık destekli eğitsel oyunların dağıtımının yapılması gerekiyor. TUBİTAK Ortaokul 
araştırma projelerinde derecelerimiz var bu alanda. Anlatma becerisini geliştirmeye çalışıyoruz."

Ö6: "Oldukça yeterli hissediyorum. Kendime ait konuşma becerisini geliştirmeye yönelik oyunlarım var birkaç tane."

Ö7: "Yeterli görüyorum. Bu konuda öğretmenler daha çok araştırma yapmalı. Geliştirdiğim bir oyun var, makale olarak da yayınladım, daha çok kutu oyunları geliştirmeye çalışıyorum ama vakit buldukça."

Ö8: "Evet, yeterli hissediyorum. Dersimde kullanmak üzere tasarladığım oyun var."

\section{SONUÇ VE TARTIŞMA}

Türkçe öğretmenlerinin eğitsel oyunlara yönelik görüşlerinin değerlendirildiği bu araştırmadan elde edilen sonuçlar ve bu sonuçlarla paralel olan diğer araştırmaların sonuçlarına bu bölümde yer verilmiştir.

Öğrencinin sürecin içinde yer aldığı yaparak yaşayarak öğrenme Türkçe öğretmenlerine göre en etkili yöntemdir. Karataş (2014) çalışmasında öğrencinin aktif olarak katıldığı oyunlaştırma yöntemine yönelik yapılan araştırmaların son dönemlerde arttığına ve bu yönteme yönelik eğilimlerin her alanda yaygınlaştığına dikkat çekmiştir. Kalem ve Fer (2013) çalışmalarında aktif öğrenmenin öneminden bahsetmiş, eğitimde gerekli olduğunu vurgulamışlardır. Türkçe öğretmenlerinin derslerinde en sık kullandıkları yöntem ve teknikler ise buluş yoluyla öğrenme, gösterip yaptırma, beyin firtınası, tartışma, problem çözme, soru cevap ve oyunlaştırmadır.

Öğrencinin eğlenmesine ve hoşça vakit geçirmesine neden olan her şeyi oyun olarak tanımlayan Türkçe öğretmenlerine göre eğitsel oyun; belirli kuralları olan, yetenek ve zekâ geliştiren, eğlendirirken öğreten eğlenceler bütünüdür.

Türkçe öğretmenleri eğitsel oyunların her derste olduğu gibi Türkçe derslerinde de gerekli olduğuna inanmaktadır. Tortop ve Ocak (2010) da sinıf öğretmenlerinin eğitsel oyunlar hakkında görüsslerini aldıkları çalışmalarında eğitsel oyunların eğitimde kullanılması gerektiğini vurgulamışlardır. Özdemir ve Ramazan (2014) da okul öncesi öğretmenleri ile yaptıkları görüşmelerde benzer sonuçlara ulaşmıştır. Özenç (2007) öğretmenlerin ilk okuma ve yazma çalışmalarında eğitsel oyunları kullanmaya yönelik görüşlerini aldığı çalışmasında oyunun çocuğun her döneminde gerekli olduğunu ve okuma ve yazma çalışmalarında da kullanılması gerektiğini vurgulamıştır. Öztemiz ve Önal (2013) öğrencilere okuma alışkanlığ kazandırmada eğitsel oyunların önemini vurgulamışlardır. Oyunlarla iç içe olan öğrencilerin hem Türkçe dersine karşı 
motivasyonlarının ve odaklanmalarını arttıracağı için hem de Türkçe dersinin etkili, kalıcı, eğlenceli hâle gelmesinde eğitsel oyunları gerekli görmüşlerdir. Türkçe öğretmenleri konuyu pekiştirmek, güncel yaşamla ilişkilendirmek, kalıcı, etkili ve eğlenceli Türkçe öğretimi yapmak için eğitsel oyunları kullanmaktadır. Romine (2004) ön test- son test olarak yaptığı araştırmada oyunların öğrencilerin motivasyonlarını, aktif katılımlarını ve öğrenilenlerin kalıcılığını geliştirdiğini belirtmiştir. Klein ve Freitag (1991) da çalışmalarında benzer sonuçlara ulaşmışıtır. Özer ve arkadaşları (2006) ile Koçyiğit ve arkadaşları (2007) ve Gedik (2017) eğitsel oyunların öğrencilerin etkili, kalıcı ve eğlenceli bir şekilde öğrenmesini sağladığına çalışmalarında değinmiş̧lerdir. Eğitsel oyunların akademik başarıyı olumlu etkilediğini belirten çalışmalar da araştırmanın sonucu ile paralellik göstermektedir (Babaandaç, 2013; Bilsoy, 1992; Coşkun, 2012; Gedik, 2012; Yazıcıoğlu, 2017, Akın ve Atıc1, 2015).

Türkçe öğretmenleri, 3, 4, 5, 6, 7, 8 ve 9. sınıflardaki derslerinde eğitsel dijital oyunları kullanmakta ve beş ya da altı saatlik haftalık Türkçe ders saatinin bir ya da iki saatini eğitsel oyuna ayırmaktadır.

Türkçe öğretmenlerine göre eğitsel oyunlar, derslerde etkili olmakta, öğrencileri motive etmekte, grup içi iş birliği ve iletişimin gelişiminde olumlu katkıları olmaktadır. Eğitsel oyunların derslerde etkili olup olmamasını; BİLSEM Türkçe Öğretim Programının esnek olup olmaması, öğretmen ve öğrencinin hazırbulunuşluğu, konuların uygunluğu ve grupların kalabalık olup olmama durumu etkilemektedir.

Türkçe öğretmenleri derslerinde birçok eğitsel oyundan yararlanmaktadır. Bunlar: Kelime oyunları, masaüstü oyunları, kart ve kutu oyunları, sözel zekâ oyunları, hikâye kartları, drama görselleri, atasözü ve deyim kartları, hikâye küpleri, tabu, pandomim gibi eğitsel oyunlardır.

Türkçe dersinin dinleme, konuşma, okuma, yazma gibi dil becerilerini kazandırmak ve soyut kavram ve kuralları içeren dil bilgisini öğretmek için eğitsel oyunlardan yararlanılmaktadır. Türkçe öğretmenlerine göre eğitsel oyunlar, her beceri ve her konunun öğretiminde kullanılabilir. Türkçe öğretmenlerine göre Türkçe dersi bir bütün olarak işlenmeli, beceriler bir arada verilmelidir. Eğitsel oyunlar özellikle kelime ve kavram öğretiminde, söz varlığını zenginleştirmede, hazırlıksız konuşma, yaratıcı düşünme becerilerini geliştirmede, yaratıcı yazma becerilerinde daha fazla tercih edilmektedir. Altun (2013) yaptığı çalışmasında eğitsel oyunların öğrencilerin problem çözme, Bulut (2015) yaptı̆̆ çalışmasında ise eğitsel oyun tasarımının yaratıcı düşünme becerilerini geliştirdiğini belirtmiş̧tir. Varan (2017) ilkokul öğrencilerine kelime öğretmek için eğitsel oyunlardan yararlandığ 1 çalışmasında eğitsel oyunların zihinsel sözlüklerini geliştirmede etkili olduğunu belirtmiştir. Gözalan ve Koçak 
(2014) da çalışmalarında kelime öğretiminde eğitsel oyunlardan yararlanmış ve başarı kaydetmişlerdir. Keskin (2009) tarafından yapılan çalışmada ise sınıf içi ve dar alan oyunlarının öğrencilerin çoklu zekâ alanlarının gelişmesine katkı sağladığı, farkında olmadıkları yeteneklerini ortaya çıkardığı, daha çok motive oldukları ve keyifli ders işledikleri belirtilmiştir. Demir (2016) hafif zihinsel engelli öğrencilerle yaptığı çalışmasında yazı farkındalığı oluşturmak için yazıca zenginleştirilmiş eğitsel oyunlardan yararlanmış ve oyunların yazma becerisinde etkili olduğunu belirtmiştir.

Türkçe öğretmenleri eğitsel oyunları öğretmen, öğrenci, sınıf yönetimi açısından yararlı olarak değerlendirmiştir. Türkçe öğretmenlerine göre eğitsel oyunlar, hem öğretmen için hem de öğrenci için doyum sağlamakta, derse katılım fazla olduğundan konuları öğretmek daha kolay, etkili ve eğlenceli olmaktadır. Az ilgi gören, soyut konuların öğretilmesinin ve öğrenilmesinin kolaylığını sağlamakta, öğretilen konular pekişmekte ve somutlaşmakta ve gerçek yaşama aktarımı kolay olmaktadır. Grup içinde iş birliğini arttırmakta öğrencilerin kurallara uyma, sabretme, öz denetim, empati gibi beceri ve değerleri kazanmalarına yardımcı olmaktadır. Gülhan (2012) ve Durualp ve Aral (2010) eğitsel oyunların öğrencilerin sosyal beceri seviyelerinde gelişme sağladığını, Çankaya (2014) öğrencilerde empati becerisini geliştirdiğini araştırmalarında belirtmiş̧ir. Dersler aktif katılımın olduğu bir ortamda işlendiğinden eğitsel oyunlar sınıf yönetimine öğretmen açısından katkı sağlamaktadır.

Türkçe öğretmenlerine göre öğretmen eğitsel oyunların konuya ve sınıf / grup mevcuduna uygunluğuna, rehberliğini iyi düzeyde yapmasına, oyunun bir amaca hizmet etmesine dikkat etmelidir. Bu durumlarda yetersiz olan bir öğretmenin dersin işlenişinde sınıf yönetiminin de olumsuz olacağını bildirmişlerdir.

Türkçe öğretmenleri, eğitsel oyunlara ulaşmak için gerek eğitsel oyun kitaplarından gerekse Instagram, Facebook, Youtube gibi sosyal ortamlardan yararlanmaktadır. Bazı Türkçe öğretmenleri ise kendi çalışmalarını öğrencilerin yaşantılarından yola çıkarak hazırlamakta ya da tasarlamaktadır.

Türkçe öğretmenleri hem eğitsel dijital oyunları kullanmada hem de oluşturmada yeterli donanıma sahiptir. Eğitsel oyunlarla ilgili eğitim aldıklarını, araştırma yaptıklarını, güncel bilgileri takip ettiklerini, akademik çalışmalar yaptıklarını, TUBITAK projeleri hazırladıklarını belirtmişlerdir. Bazı Türkçe öğretmenleri eğitsel oyunların Millî Eğitim Bakanlığ tarafından temin edilmesi gerektiğini, Türkçe öğretmenleri bu oyunlara ulaşamayınca mecburen kendilerinin hazırladıklarını, bu durumun da çok zaman aldığını vurgulamışlardır. 


\section{ÖNERÍLER}

Araştırmadan elde edilen sonuçlara yönelik şu önerilerde bulunulabilir:

Türkçe dersinin dinleme, konuşma, okuma, yazma kazanımlarına uygun eğitsel oyunlar geliştirilebilir.

Öğretmenlerin bireysel çabalarının yanı sıra eğitsel oyunlara zaman kaybı olmadan ulaşmaları için Millî Eğitim Bakanlığı destek sağlamalıdır.

Tasarlayan, üreten kısaca kendi materyalini, dersini kendi oluşturabilen / tasarlayabilen Türkçe öğretmenleri yetiştirmek için gerek Türkçe öğretmeni adaylarına gerekse okullarda olan Türkçe öğretmenlerine bu konuda eğitim verilmelidir.

Bilim Sanat Merkezlerinde görev yapan Türkçe öğretmenlerinin tasarladıkları / hazırladıkları eğitsel oyunların tanıtılmasına ve bu oyunları, farklı Türkçe öğretmenlerinin de bilmesine, kullanmasına fırsat tanınmalıdır.

Okullarda çalışan Türkçe öğretmenlerinin de eğitsel oyunlar hakkındaki görüşlerine yer veren çalışmalar yapılabilir.

\section{KAYNAKÇA}

Akın, F. A. ve Atıcı, B. (2015). Oyun tabanlı öğrenme ortamlarının öğrenci başarısına ve görüşlerine etkisi. Turkish Journal of Educational Studies, 2(2), 75-102.

Altun, M. (2013). Düzenli ĕgitsel oyun oynayan 11-12 yaş grubu çocuklarda problem çözme becerisinin incelenmesi [Yayımlanmamış yüksek lisans tezi]. Gazi Üniversitesi.

Arkün Kocadere, S. ve Samur, Y. (2016). Oyundan oyunlaştırmaya. İçinde A. İşman, F. Odabaşı ve B. Akkoyunlu (Ed.), Eğitim Teknolojileri Okumaları 2016 (ss. 397-414). TOJET-Sakarya Üniversitesi.

Ayan, S. ve Dündar, H. (2009). Okul öncesi eğitimde yaratıcılı̆̆ın ve oyunun önemi. Selçuk Üniversitesi Ahmet Keleşoğlu Ĕ̆itim Fakültesi Dergisi, 28, 63-74.

Babaandaç, B. (2013). Oyunlarla öğretimin insan ve çevre ünitesinde ögrencilerin akademik başarılarına ve kalıcılı̆̆a etkisi [Yayımlanmamış yüksek lisans tezi]. Niğde Üniversitesi. 
Bilsoy, E. (1992). Suggested games to enhance grammatical correctness and communicative effectiveness in English language teaching [Yayımlanmamış yüksek lisans tezi]. Orta Doğu Teknik Üniversitesi.

Bulut, D. (2015). Eğitsel oyun tasarlama sürecinin ögrencilerin yaratıcılıklarına etkisi [Yayımlanmamış yüksek lisans tezi]. Bahçeşehir Üniversitesi.

Coşkun, H. (2012). Bilimsel öyküler içeren eğitsel oyunlar ile fen ögretiminin ögrencilerin akademik başarısına etkisi [Yayımlanmamış yüksek lisans tezi]. Erciyes Üniversitesi.

Çağdaş, A. ve Şahin Seçer, Z. (2002). Çocuk ve ergende sosyal ve ahlak gelişimi. Nobel Yayıncilik.

Çankaya, G. (2014). Çocukların oynadıkları oyunlara göre empati ve saldırganlık düzeylerinin incelenmesi [Yayımlanmamış yüksek lisans tezi]. İstanbul Üniversitesi.

Çoban, B. ve Nacar, E. (2015). Ortaokullarda eğitsel oyunlar. Nobel Akademik.

Demir, M. (2016). Yazıca zenginleştirilmiş oyunun anaokuluna devam eden zihinsel engelli öğrencilerin yazl farkindalı̆̆ becerilerine etkisi [Yayımlanmamış yükssek lisans tezi]. Gazi Üniversitesi.

Demirel, Ö. (2007). Öğretme sanatı: ögretim ilke ve yöntemleri. Pegem A.

Durualp, E. ve Aral, N. (2010). Altı yaşındaki çocukların sosyal becerilerine oyun temelli sosyal beceri eğitiminin etkisinin incelenmesi. Hacettepe Üniversitesi Eğitim Fakültesi Dergisi, 39, 160- 172.

Gedik, M. (2012). Ortaokul ikinci sinıf öğrencilerinin temel dil becerilerinin gelişstirilmesinde ĕgitsel oyunları başarı ve kalıcıllğa etkileri [Yayımlanmamış doktora tezi]. Atatürk Üniversitesi.

Gedik, M. (2017). Ortaokul 2. sinıf öğrencilerinin okuma becerilerinin geliştirilmesinde eğitsel oyunların başarı ve kalıcılığa etkisi. Türkiyat Araştırmaları Enstitüsü Dergisi, 58, 453-464.

Gözalan, E. ve Koçak, N. (2014). Oyun temelli dikkat eğitim programının 5-6 yaş çocukların kelime bilgi düzeylerine etkisinin incelenmesi. Karamanoğlu Mehmetbey Üniversitesi Sosyal ve Ekonomik Araştırmalar Dergisi, 4, 115-130. 
Gülhan, G. (2012). 10-12 yaş grubu ilköğretim öğrencilerinin sosyal beceri düzeyleri üzerine eğitsel oyunların etkisi [Yayımlanmamış yüksek lisans tezi]. Gazi Üniversitesi.

Güngörmüş, G. (2007). Web tabanlı eğitimde kullanılan oyunların başarlya ve kalıcılığa etkisi [Yayımlanmamış yüksek lisans tezi]. Gazi Üniversitesi.

Henniger, M. L. (2005). Teaching young children (an introduction). Pearson Merrill Prentice Hall.

Kalem, S. ve Fer, S. (2003). Aktif öğrenme modeliyle oluşturulan öğrenme ortamının öğrenme, öğretme ve iletişim sürecine etkisi. Kuram ve Uygulamada Ĕ̈itim Bilimleri, 3(2), 433- 461.

Karabacak, N. (1996). Sosyal bilgiler dersinde eğitsel oyunların ögrencilerin erişi düzeyine etkisi [Yayımlanmamış yüksek lisans tezi]. Hacettepe Üniversitesi.

Karataş, E. (2014). Eğitimde oyunlaştırma: araştırma eğilimleri. Ahi Evran Üniversitesi Kırşehir Eğitim Fakültesi Dergisi, 15(2), 315-333.

Keskin, A. (2009). Oyunların çocukların çoklu zekâ alanlarının gelişimine etkisi [Yayımlanmamış yüksek lisans tezi]. Selçuk Üniversitesi.

Klein, J. D. ve Freitag, E. (1991). Effects of using an instructional game on motivation and performance. Journal of Educational Research, 84(5), 303308.

Koçyiğit, S., Tuğluk, M. N. ve Kök, M. (2007). Çocuğun gelişim sürecinde eğitsel bir etkinlik olarak oyun. Atatürk Üniversitesi Kazım Karabekir Eğitim Fakültesi Dergisi, 16, 324-342.

Mangır M. ve Aktaş, Y. (1993). Çocuğun gelişiminde oyunun önemi. Yaşadıkça Eğitim Dergisi, 26, 14-19.

MEB (2019). Türkçe dersi öğretim programı ilkokul ve ortaokul 1, 2, 3, 4, 5, 6, 7 ve 8. sinıflar. Millî Eğitim Bakanlığı.

Miles, M. B. ve Huberman, M. A. (2015). Nitel veri analizi. (Ç. Ed: S. Akbaba Altun-A. Ersoy). Pegem Akademi.

Öğretir, A. D. (2008). Oyun ve oyun terapisi. Gazi Üniversitesi Endüstriyel Sanatlar Eğitim Fakültesi Dergisi, 22, 94-100. 
Özdemir, A. ve Ramazan, O. (2012). Oyuncağa çocuk, anne ve öğretmen bakış açısı. Eğitim Bilimleri Araştırmaları Dergisi, 2(1), 1-16.

Özdemir, A. ve Ramazan, Oya (2014). Okul öncesi öğretmenlerinin oyuna ilişkin görüşleri. Eğitim Bilimleri Araştırma Dergisi, 3(4), 298-308.

Özenç, E.G. (2007). İlk okuma ve yazma ögrretiminde oyunla öğretim yöntemine ilişkin ögretmen görüşlerinin incelenmesi [Yayımlanmamış yüksek lisans tezi]. Marmara Üniversitesi.

Özer, A., Gürkan, A. C. ve Ramazanoğlu, M. O. (2006). Oyunun çocuk gelişimi üzerine etkileri. Doğu Anadolu Bölgesi Araştırmaları, 5(1), 54-57.

Öztemiz, S. ve Önal, H. İ. (2013). İlkokul öğrencilerinin oyun tekniği ile okuma alışkanlığ1 kazanmasına yönelik öğretmen görüşleri: Ankara Beytepe İlkokulu örneği. Bitlis Eren Üniversitesi Sosyal Bilimler Dergisi, 2(1), 6579.

Özyürek, A. ve Çavuş, Z. S. (2016). İlkokul öğretmenlerinin oyunu öğretim yöntemi olarak kullanma durumlarının incelenmesi. Kastamonu Ĕgitim Dergisi, 24(5), 2157-2166.

Pehlivan, H. (2005). Oyun ve ögrrenme. Anı Yayıncılık.

Romine, X. (2004). Using games in the classroom to enhance motivation, participation, and retention: a pre-test and post-test evaluation. In D. A. McAllister, S. M. Bothman (Eds.), Culminating Experience Action Research Projects 5, (pp. 283-295). The University of Tennesse at Chattanooga.

Russ, S. W. (2003). Play and creativity: developmental issues. Scandinavian Journal of Educational Research, 47, 291-303.

TDK. (2020, 17 Ocak). Güncel Türkçe sözlük. https://sozluk.gov.tr/

Tortop Y. ve Ocak, Y. (2010). Sınıf öğretmenlerinin eğitsel oyun uygulamalarına yönelik görüşlerinin incelenmesi. Spor ve Performans Araştırmaları Dergisi, 1(1), 14-22.

Ulutaş, A. (2011). Okul öncesi dönemde drama ve oyunun önemi. Adlyaman Üniversitesi Sosyal Bilimler Enstitüsü Dergisi, 4(6), 32-35.

Varan, S. (2017). İlkokul 4. sinıf öğrencilerinin zihinsel sözlüğünü geliştirmede eğitsel oyunların etkisi [Yayımlanmamış yüksek lisans tezi]. Bartın Üniversitesi. 
Yavuzer, H. (2017). Çocuk psikolojisi. Remzi Kitabevi.

Yazıcıoğlu, S. (2017). Oyun temelli etkinliklerin ortaokul 6. sınıf öğrencilerinin akademik başarılarına, fen ögrenmeye yönelik motivasyonlarına ve tutumlarına etkisi: ışılk ve ses ünitesi örneği [Yayımlanmamış yüksek lisans tezi]. Giresun Üniversitesi.

Yıldırım, A. ve Şimşek, H. (2013). Sosyal bilimlerde nitel araştırma yöntemleri (9. bask1). Seçkin Yayıncılık.

Yurdakul, B. (2005). Yapılandırmacılık. İçinde Ö. Demirel (Ed.), Eğitimde Yeni Yönelimler, (ss. 39-64), Pegem Akademi. 